Artigos/Articles

\title{
Reviewing Critical Research Methodologies for Teacher Education in Applied Linguistics
}

\author{
Revisando Metodologias Críticas de Pesquisa para \\ formação de professores em Linguística Aplicada
}

Maria Cecilia Camargo Magalhães ${ }^{1}$

Sueli Salles Fidalgo ${ }^{2}$

\section{ABSTRACT}

The field of Applied Linguistics has undergone several changes in the last years, and, in various aspects, it can be considered today as movable praxis (Pennycook, 2001:173). This text reviews Critical Research Methodologies, by firstly looking at the history of the field, and analyzing how it has changed over the years, comparing such methodologies as Action Research (AR); Participative Research (PR) and Critical Collaborative Research (PCCol) considering that these, to a greater or lesser degree, intervene in the context where they organize the research carried out. We then deepen our discussion of PCCol - theory-methodology used by our research groups: LACE, ILCAE and GEICS ${ }^{3}$.

1. Pontifical Catholic University of São Paulo. São Paulo - Brasil. https://orcid.org/00000002-8567-0358. E-mail: cicamaga@gmail.com.

2. Federal University of São Paulo. São Paulo - Brasil. https://orcid.org/0000-0001-65332346. E-mail: ssfidalgo@terra.com.br.

3. These research groups are accredited by $\mathrm{CNPq}$ - National Research Council - and by the universities where their leaders carry out their investigations: LACE stands for Languages in Activities in Educational Contexts and is led by M. Cecília C. Magalhães and Fernanda C. Liberali at PUC-SP; ILCAE stands for Linguistic Inclusion in Scenarios of Educational Activities and its leaders are Angela B. Cavenaghi T. Lessa and Sueli S. 
Keywords: Critical Research methodologies, teacher education, Applied Linguistics, Critical Collaborative Methodology.

\section{RESUMO}

O campo da Linguística Aplicada transformou-se nos últimos anos e, em vários aspectos, pode ser considerado hoje como "uma prática móvel" (Pennycook (2001: 173). Este texto analisa Metodologias Críticas de Pesquisa, examinando primeiramente a história do campo e as mudanças ao longo dos anos, comparando metodologias como Pesquisa-Ação (PA); Pesquisa Participativa (PR); Pesquisa Crítica de Colaboração (PCCol), considerando que estes, em maior ou menor grau, intervêm no contexto em que a pesquisa é realizada. Em seguida, aprofundamos nossa discussão sobre a PCCol-base teórico-metodológica de nossas investigações, bem como de nossos Grupos de Pesquisa: LACE; ILCAE e GEICS. ${ }^{4}$

Palavras-chaves: Metodologias Críticas em Pesquisa, Formação de Professor, Linguística Aplicada, Metodologia Crítica de Colaboração.

\section{Introduction}

We initiate this text by situating ourselves: we are Applied Linguists who work with teacher education by following interventionist research methodologies, within the framework of the Sociocultural-Historical and Activity Theories. In terms of Applied Linguistics, it is important to mention that the field has experienced several transformations, and can probably be considered movable praxis (Pennycook, 2001:173), i.e., an area where investigations are "constantly shifting", dynamically challenging itself to try to answer questions that reflect matters regarding language, education, language teaching-learning, among others that are carried out within social spheres. For this reason, Pennycook (2001:173) states that he prefers to see this field " as a form

Fidalgo at PUC-SP and UNIFESP; GEICS stands for Studies about the Deaf's Identity and Culture and is led by Sueli S. Fidalgo and Sandra R. L de Campos at UNIFESP.

4. Linguagem em Atividades no Contexto Escolar (LACE) PUC-SP/ CNPq, líderes Magalhães e Liberali; Grupo de Pesquisa: Estudos sobre Identidade e Culturas Surdas (GEICS) UNIFESP/CNPq, líderes Fidalgo e Campos; Inclusão Linguística em Cenários de Atividades Educacionais ( ILCAE) PUC-SP/ CNPq e UNIFESP, líderes Angela Lessa e Sueli Fidalgo. 
of antidisciplinary knowledge, as a way of thinking and doing that is always questioning, always seeking new schemas of politicization." Some of the devices for politicization employed in Applied Linguistics are those known as Critical Research methodologies, especially when used in education and the education of educators.

This paper will focus on the discussion of some of these methodologies. More specifically, it aims at historically reviewing the Critical Research Paradigm, by looking at how it has changed over the years with the appearance of methodologies as Action Research (AR) (Barbier, 2002; Thiollent, 2004, Kincheloe, 1993), Participative/ Participatory (Action) Research (PR) (Demo, 2004; Denzin and Lincoln, 2008) and Critical Collaborative Research (PCCol) (Magalhães, 19902018; Bray et al., 2000; Beaumont, 2000) - which we discuss in this order. Considering that these, to a greater or lesser degree, intervene in the context where they organize the research carried out, we will follow the above debate with some considerations as to their roles in the educator's education. We will then deepen our discussion of PCCol - methodology that bases most of our investigations.

We consider it essential to discuss research methodologies in educators' education, especially when we look at the current context of power struggle that takes place between defenders of a globalized, neoliberal world and those that see migratory, economic, cultural and political changes as constitutive of the countries. This is even more evident in a country where a neoliberal political organization constantly seems to aim at devaluing the field of education by employing hierarchical, top-down approaches to teaching-learning, evaluating programs, educators, schools, and even to select school projects that are eligible for financial support - which sometimes seems to draw a fine line between a legitimate and necessary evaluation process of educational actions and a kind of witch hunt of whatever resembles critical thinking. After all, as pointed out by Kincheloe and McLaren (2000: 305), working within Critical Research is participating in a critical design of the world - and one which is guided by a plan of a dream (yet unfinished as dreams are) - where the world sees less misery, and suffering, and less politics and policies based on falsehood. On the contrary, where the policies are challenging of the problems that society has to face (or look in the eye). 
Bearing this entire political-theoretical and philosophical debate in mind, we look at critical methodologies, by asking ourselves the following questions:

- Do all methodologies aim at understanding and transforming the context or do some seek solely to understand the status quo?

- In which case(s) does the researcher work with, on or for the researched participant?

We initiate our discussion by focusing on the concepts of critical theory and Critical Research that are key ones to this paper and next we will discuss the methodological approaches: Action Research (AR), Participative/Participatory (Action) Research (PR) and Critical Collaborative Research (PCCol).

\section{Critical Theory, Critical Research: what is this?}

Critical Theory goes back to Marx and Engels (1845-6), and has been interpreted by several authors in a number of fields of investigation - the most well-known of which is perhaps the School of Frankfurt, and in Brazilian educational system, those that work with Critical Pedagogy. Under this subheading, we will see Freire (1970) and his followers, McLaren, Kincheloe, Giroux among others.

Freire's ideas of critical theory (that supports his critical pedagogy) included a discussion about power relations and methodologies of change aiming at individual and collective empowerment through a process of awareness development about binding and restrictive situations. In order for this empowerment to take place, critical theory emphasizes that the reality of oppression needs to be transformed through dialectical dialogues that ultimately aim at rejecting the positivist notions of rationality, objectivity and single truth or single story (Chimamanda, 2009) - which according to this author, "flattens experience."

Critical Research must therefore be an attempt to confront unfairness; an effort to implement dialectical relations, allowing for world contradictions to come forth and domineering cultural features to be challenged. As part of the school, critical theory must be a process of hope where joint work between different agents (researcher, 
teacher, students, other staff members, parents and the surrounding communities) takes place, ultimately transforming the school, the society and participants themselves as part of the process.

\section{Comparative historical review of critical methodologies}

There is a growing number of research methodologies, and the same holds true for those in the area of Critical Theory. We are unlikely to cover all of them. Besides, there are several different definitions and interpretations for methodologies or approaches (Kincheloe and Mclaren, 2000: 280) such as Participatory/Participant/Participative, Action, Collaborative Action, and Collaborative Research, among others. This specificity will not be the aim of our discussion, nor will we contend or support the view that some participative and action works are developed within other paradigms that are not critical because this is a matter for other texts. Our focus is to - in the macro-area of Qualitative Research - compare methodologies that compose the Critical Paradigm, showing where some have seemed (to us) to fall short - and how this has led us to the Critical Collaborative Research, itself a methodology that has been under development for the last twenty-eight years, initiated by Magalhães in 1990 with her doctoral study.

We will start by looking at Participatory (ive) Research, and will discuss Action Research before moving to Critical Collaborative Research, and in each case, we will try to address the questions posed earlier.

\section{Participatory (ive) Research}

According to Bray et al. (2000) and Demo (2004), this methodology goes back to the 1960s when it was initiated as an integrated activity combining concerns of the society, work, education and action, i.e., a type of research that is politically focused, theoretically-initiated, based on the community and their concerns: their problems, their aims and dreams. It is important to highlight, however, that there seems to be more than one type of participatory (ive) research: it may be theoryinitiated, and therefore, take the understanding of applied research that results from theory (i.e, Le Broterf's model, cited by Demo, 2004: 97, 
which starts from a hypothesis and concepts, and looks into the different variables before proposing transformation into a new type of practice). It might also be practice-initiated (as in Freire's work in Angicos, Northeastern Region of Brazil, which starts from the worker's daily concerns and words that are generated from their own professions in order to educate these very workers, thus transforming their oppressive positions). In both cases, it is politically driven.

Demo (2004: 76) calls our attention to the danger of research that is theory-initiated (or even based), stating that it may be disconnected from practice (always a fine line), arguing that this type of research does not actually reach the status of a "theory," since practice is a criterion for the establishment of truthfulness. And he further argues that, from a single theory a number of practices can be derived, some of which may even contradict others (Demo, 2004: 76); i.e., Marxist theories that have developed into different kinds of practices. Therefore, the danger of establishing that research is theory initiated is that each different theoretical interpretation might lead to different practices. It may also lead to doubts about the position taken by research participants: are they beneficiaries of the research, members of the micro or larger community involved or initiators of the research? And what is the position of the researcher themselves?

To answer these questions, according to Demo (2004: 93),

Problem is initiated in the community or in the working place; Research should ultimately aim at structural transformation and the improvement of the lives of those involved; the beneficiaries being the workers or the people involve.

Therefore, Participatory (ive) Research includes the people, the community, who are/is "in control of the entire research process, " and should, for this reason, be "conscious of their abilities and resources", and of the support that they need in order to carry out the transformation necessary. The researcher may be a member of the community, but is rarely an outsider. When the researcher is an outsider, it is because they have special training or knowledge, but they must be committed with the community and their entire learning process, "leading more often to political engagement than to distancing” (Demo, 2004: 94). 
Still, as Demo himself poses (2004: 120), the scholar is not a proletarian. There may be ideological identity between these two individuals when they are members of the same research organization, but the former does not suffer the same effects from the oppressive system that they are both trying to confront. In Brazilian society, for example, we can say that they do not receive the same poor salaries or are prone to losing their formal jobs, having to conform to informal job market or working conditions depending on the results of the investigation. The former belongs to a scholarly elite despite not being necessarily a member of a socioeconomic elite. In this sense, focusing on the transformation of the proletarian's reality (to which the scholar does not really adhere or belong) might be similar to developing a one-way investigation, which can place the scholar in the position of a consultant, i.e., someone with knowledge or expertise that can assist in the transformation of a working place or community. By the same token, it may place the participant on a lower position, on the recipient end when it comes to data analysis and publication of research results, often credited to the researcher. This challenge may have led to some of the developments seen in Action Research, our focus on the next section.

\section{Action Research}

Initially, Action Research was seen as methodology developed by the community or group. However, there are, today, many types of Action Research, so much so that Andaloussi (2004: 72) calls it action "researches," arguing that, especially in the field of education, one can see such terminologies as "Action Research, Development Research, Innovation Research, Participation Research, Active Research, Actions Research, Operational Research, Operative Research, Guided Research, Implied Research, among others. Some are aimed at problem solving and therefore, according to the author, are oriented to the implementation of a plan - which is not always collectively developed. But, as does Andaloussi (2004: 73), in this text, we will look only at three major trends of Action Research.

Going back to the works of the pragmatist Dewey in the late 1920s, the researchers who follow the first type of Action Research consider that practitioners are better informed to use the results of 
the investigation if they are also on the developing end of such work. Today, this has led to the understanding that Action Research is a sound method for investigation in the educational field (Andaloussi, 2004 e Nunan, 1986). This is not always Critical Research however. Sometimes it is technical or practical research based (Pérez Gomez, 1997: 96-106; Kemmis, 1987: 74-80) on reflection practices of the former or latter kind. Discussing Andelman (1993), Andaloussi (2004: 76) cites the Participative Action Research - that seems to us to follow the concept of Practical Reflection - and the Experimental Action Research - that is defined in similar terms as Technical Reflection. In its definition, the first assumes that the members of a community should be assisted whilst being participants of the research. It aims at solving local problems that might later be used as examples for other communities. This type of research, says the author (p.76) does not allow for the development of general principles. On the other hand, the experimental Action Research "aims at controlling the efficacy of techniques in seemingly identical situations", and allows for a definite test of scientific hypotheses.

The second trend in Action Research is called militancy Action Research (Andaloussi, 2004: 78) and is used in situations where there is a clear need for engaging in movements that oppose dictatorial positions, as was the case of investigations carried out in Latin American during the dictatorship regimes (Andaloussi, 2004: 79). However, the author himself states that it there is a danger that these experiences may lead to the manipulation of the community (or the people) towards his or her political project.

Andaloussi (2004) says that the third trend is the current paradigm of action research, and that one of the many types of studies that compose it is the one concerned with solving problems and improving situations or strengthening a weaker sector of the community. The actors (or agents in a broader sense) are all the people who are interested in the problem being investigated. In education, for instance, it may include teachers, parents, the principal and other members of the managerial team, decision makers, the surrounding community. People will take on different roles: some will solely observe. And "participants will seek to establish a partnership that will enable them to manage the difficult balance between research, action and decision making" (Andaloussi, 2004: 88). 
Perhaps for this reason, some authors, such as Beaumont et al. (2000: 85) state that today, "action research may contribute to the overall research base, but in essence it is more concerned with teacher development than it is with the generation of hard data." And, although, in the late 1990s, it was seen as a "valuable professional development tool or an 'inside-out' approach to professional development - which place[d] practitioners, or community members at the centre of the inquiry process" (Nunan, 1986: 21), it has since been acknowledged that schools' circumstances and conditions often make it hard for teachers to research their classrooms. In other words, time and financial constraints, lack of incentives (results do not always lead to promotion for example), lack of resources and consent, among other matters make it hard for the teacher to investigate their own practices. Besides, due to the belief that it is the university academic researcher's role to produce knowledge, researching by teachers is seen in schools, by peers and superiors, as downright wrong. The investigative work is therefore often met with overall disapproval.

This general frame of lack of support many times leads individualized work - a teacher, in his or her classroom, who carries out research to improve his/her practice with his/her students. This leads back to the first type of action research discussed previously. And in this sense, it is not always critical because it is either practice based and practice generated (based on practical reflection), based on the works of Dewey; or theory based and theory generated (based on technical reflection).

In many of the above frames, the action research falls short to the definition provided by Greenwood and Levin (2007: 3), who state that

Action research is social research carried out by a team that encompasses a professional action researcher and the members of an organization, community or network ("stakeholders") who are seeking to improve the participants' situation. AR promotes broad participation in the research process and supports action leading to a more just, sustainable, or satisfying situation for the stakeholders.

Because it either has the researcher's best interest at heart (their need to complete the investigation) or it is carried out by a teacher who is often not a "professional action researcher", or it is carried out by a 
teacher who is a professional researcher too, but the members of the organization are not working as a team in the investigation.

It also seems to fall short to the definition provided by Demo (2004), for whom any type of critical participatory research has to be looked at from a dialectical perspective. One needs to produce knowledge and participation at the same time; knowledge and transformation of the actions that compose the situation where the problem was found, commitment with the research and concrete changes - all at once. This leads us to the use of collaboration in research, and to seek to understand practice - as well as the theory that underlies it.

\section{Critical Collaborative Research}

Contrary to Critical Collaborative Research, the other methodologies described here, even those that are critically based, focus on historical and cultural matters, but do not take into account the Sociohistorical Theory (Vygotsky), which sees it as essential to describe and discuss the context of production, and participants as agents in processes of development that are mediated by cultural artifacts. The authors' historical views seem to be a teleological understanding (to a greater or lesser degree) rather than a dialectical view of development, as is Vygotsky's.

It is also important to clarify that, as with Action Research, so too Collaborative Research might be carried out within a Critical or an Interpretive perspective. The latter is closer to a view of cooperation - which establishes a relationship that does not allow participants to challenge the given reasoning processes, or their own psychological organizations, simply because cooperation does not allow for contradictions, conflict and the reorganization that results from them. In actual terms, cooperating is traditionally seen in connection with an overuse of politeness maxims because it exists within the idea of providing aid instead of dealing with a problem that may even arise from the relationships that are created and organized within (and as part of) the investigation. After all, vygotskians follow a view of instrumentand-result in research (which means that every result may lead to other investigations, being the very instrument that fosters the challenging of ideas, thus, development). What happens in cooperation is instrument- 
for-result (a pragmatical rather than a dialectical organization). In other words, in cooperation, there is no intervention; it is not essential to look at the transformation of all participants (but on the transformation of content, of a practical problem, by means of an assistance or consultancy); language organization in its argumentative (and therefore, transformative) aspects is not as important to be described (and for this very reason, it may naturalize exclusion when the linguistically powerful silence the frail, i.e., those whose argumentative skills are less developed). Researchers that use this methodology base their understanding on authors from a different epistemological view. Because this type of collaboration inhibits contradictions and conflict, Fullan and Hargreaves ([1992] 2000: 74-75) define it as "comfortable collaboration".

Critical collaboration is being constructed over the years to challenge this Cartesian view of collaboration/cooperation, by including categories such as contradiction: conflict, intervention, mediation, negotiation, resistance and what Magalhães and Fidalgo (2010: 779) have previously called "a thought-organizing-type-of-language", one that is critical because it questions lexical and structural choices, i.e., it is discourse based.

We therefore discuss PCCol as formative intervention research, based on Vygotsky's theoretical-methodological discussions (1920, 1930, 1932, 1933 and 1934) and on Engeström's perspective of Social-Historical-Cultural Activity Theory (SHCAT). As stated by Magalhães (2009:15), these authors highlight "the inseparability of epistemological and methodological issues" in order to analyze and understand relationships between the singular and the collective in research conducted for participants' critical constitution.

As seen above, this methodology is based on Marx and Engels (1845-46). It is also based on Spinozan Monism (Spinoza, 1670, 1675), and works by means of situations that are created for the participants to clarify their own mental processes, explain and demonstrate what they think and feel, recreating themselves in specific contexts and in society, by allowing for the critical expansion of their reasoning processes and their actions.

The section is also based on Vygotskian followers who are currently working on the same or similar perspective (e.g., Stetsenko, 2017; 
Holzman, 1997, 2002; Magalhães, 2011, 2012, 2013, 2015, 2016; Magalhães and Oliveira, 2016; Magalhães and Ninin, 2014; Ninin and Magalhães, 2017; Liberali, in print and AOP; Magalhães and Fidalgo, 2007, 2011; Fidalgo and Magalhães, 2017, in print; Fidalgo, 2013, 2018) who debate critical collaboration within continuous education, mediated by language.

According to Magalhães and Fidalgo (2007: 329), in an intervention research developed within a Critical Paradigm,

the primary role of applied linguists, as researchers and teacher educators, is to work with "language-bound issues as means for organizing the type of thought (...) defined in critical reflective terms, i.e., as a type of thought that might allow individuals - actual agents of their own thoughts [or reasoning processes] - to probe into their routine practices.

The focus is on the deconstruction-neoconstruction of theoreticalmethodological choices that organize educational contexts by looking into the interests they serve, so as to allow for new reasoning and acting, leading to social, political and educational transformations, as pointed out by Vygotsky (1921-23: 463-464).

Engeström's (2011) position on how to conduct interventionist research in complex contexts as activity systems, structured as chains has recently also come to support critical collaborative movements in research based on contradictions. His work, as others mentioned here are founded on vygostkian concepts that we discuss below.

\section{Vygotsky, The Methodologist}

Vygotsky is above all a methodologist. For him, the theory that supports an investigation cannot be dissociated from the method conducting the research, as pointed out by Jantzen (2005); Molon (2008); Magalhães (2009); Holzman (2009), Stetsenko (2017) among others. Molon also states that the method is not a priori or aposteriori created, but as hihghlighted by Vygotsky ([1930]1997:27), "the search for the method is one of the most important tasks of the researcher. The method, in such cases, is simultaneously a prerequisite and product, a tool and a result of the research." 
In fact, in his discussions about research methodology, Vygotsky (1920,1930,1932, 1933 and 1934) shows that he is based on Historical-Dialectical Materialism (Marx and Engels (1945-46)). For him, Marxism is the basis for the "work method" as a "historicalnatural" dialectical process (Vygotsky, [1930] 1997: 27). According to Marx and Engels (1845-46: 17), the method has a materialist and historical foundation and focuses on "real individuals, their actions and their material life conditions." Emphasis is therefore placed on the impossibility of separating theory (knowledge) and practice (action) when investigating the development of human beings.

Marx in turn seems to be based on Spinoza's Monist conception of body and soul relationship as one sole concept expressed in different way, allowing for the theoretical-practical support necessary for the discussion of relationships between biology and consciousness in the constitution of human beings as a dialectical unit.

Thus, the concepts of dialectics and monism are the foundation for the discussion of methodological units. For Vygotsky ([1934] 2001: 395-398) the main methodological problem of most of the investigations about language and thought is precisely on the relationship established between language and thought in these works. They often consider these as two separate, independent and isolated processes whose external unification allows for the appearance of verbalized thought (dualism). The meaning of a word, however, is simultaneously a phenomenon of the intellect and of discourse since both are related, both construct the meaning and the former is materialized in the latter (monism). This idea underpins the entire organization of collaborative research - which we discuss next.

\section{Critical Collaboration: a process that is assured in contradiction}

According to Stetsenko (2017: 19), "human development is a collaborative project of people together changing and co-creating the world." Based on statements such as these, one can say that collaboration is a process in which people work together to understand and transform their surroundings and, in so doing, they transform 
themselves and others in specific collective action-theory contexts. It is engendered in a continuous movement of perception, participation, self-reflection that understands practice as a means for articulation between people (i.e. research participants) in a constant, mutual and recursive process of transformation of all the involved by means of language as a cultural artifact.

Nonetheless, it is not a simple context to organize. It involves taking risks and responsibility for one's actions, and making sure, as researchers, that each participant does the same. It also requires that everyone should critically analyze practice and accept criticism as posed by John-Steiner (2000: 82), for whom collaborative contexts may be a "rather uncomfortable zone of action." Without this, new meanings are not produced, and therefore, practice-theory is not transformed. It becomes a repetitive chain rather than a creative chain (Vazquez, 1997).

Critical collaborative research goes a little further than to think of the production of new meanings. It is concerned with the process itself, with how these meanings are constructed, as it is essential that meanings are not simply replaced by those believed to be correct by the better linguistically equipped professionals, but are in fact co-constructed, thus leading to actual social transformation.

\section{Final Remarks}

We have discussed some critical methodologies, and showed the differences between them and Critical Collaborative Research - to which we adhere - for its centrality on language as a mediating tool, but also as an instrument that brings its very result and new challenges as part of its scope. Besides this, we have also showed that other concepts defined by Vygotsky (in turn based on Marx and Engels and Spinoza) are on the core of collaboration as we understand it.

PCCol, we emphasize, is a methodology that creates contexts in which participants (in our case, mostly from school environments) can act collaboratively, based on the analysis of how they engage and on a prospective view of how they would like to engage in the world. For this to be possible, we all find support on cultural artifacts that are 
sociohistorically constructed, as well as on the experiences organized with the objective of transforming the social environment, its culture and prospective history.

It is not an easy task, however. Finding the appropriate language to engage in the world, transforming it collectively, by basing one's actions on contradictions and conflict, but not on attacking anyone during this process of transformation is a very demanding task, and one that most people have trouble conducting. It is a matter of understanding the intricate organization of argumentative speeches that constructs rather than persuades. This, however, is a matter for our next paper.

\section{Reference}

ANDALOUSSI, Khalid E1. 2004. Pesquisas-ações: ciências, desenvolvimento, democracia. São Carlos: Edufscar.

ANDELMAN, Elliot. 1993. Kurt Lewin and the origins of action research. Educational action research review, v.1. n. 1.

BARBIER, René. 2000. A pesquisa-ação [Action research]. Brasília: Plano.

BEAUMONT, Mike; O'BRIEN, Teresa. 2000. Collaborative research in second language education. Trent and Sterling: Trentham Books.

BRAY, John; LEE, Joyce; SMITH, Linda; YORKS, Lyle. 2000. Collaborative inquiry in practice: action, reflection, and making meaning. London: Sage Publications.

BROOKS, Ann; WATKINS, Karen. 1994. The emerging power of action inquiry technologies. San Francisco: Jossey-Bass.

CHIMAMANDA, Adichie. 2009. The danger of a single story: talk presented at an official TED conference. Accessed on 10/27/2018 on https://www.ted.com/talks/chimamanda adichie the danger of_a_single_story?language $=$ en.

DEMO, Pedro. 2004. Pesquisa participante: saber pensar e intervir juntos [Participative Research: knowing how to collectively think and intervene]. Brasília: Liber Livro.

DENZIN, Norman; LINCOLN, Yvonna (eds.). 2008. Strategies of qualitative inquiry. Los Angeles: Sage.

ENGESTRÖM, Yrjö. 2011. From design experiments to formative interventions. Theory \& Psychology, 21(5). SAGE:598-629.

FREIRE, Paulo. 1970. Pedagogia do Oprimido. [Pedagogy of the Opressed]. Rio de Janeiro: Paz e Terra. 
FIDALGO, Sueli Salles. 2013. Inclusão ainda que às avessas. In. ELIAS, Neide e FIDALGO, Sueli Salles. Cadernos de Licenciatura em Letras: Diálogos, Lingu(agem) e Ensino em Práticas Sociais. São Paulo: Porto de Ideias.

.2018. A linguagem da exclusão e inclusão social na escola. São Paulo: Editora da Unifesp.

FIDALGO, Sueli Salles; MAGALHÃES, Maria Cecília Camargo. The method in Vygotsky's work: Focusing on Social Compensation to achieve Higher Psychological Functions. In: TANZI NETO, Adolfo; LIBERALI, Fernanda Coelho; DAFERMOS, Manolis. Revisiting Vygotsky for Social Change: Bringing Together Theory and Practice, in print.

2017. Formação de professores em contextos de inclusão: a discussão vygotskiana do conceito de compensação social. In. CELANI, Maria Antonieta Alba; MEDRADO, Betânia Passos (eds.). Diálogos sobre inclusão: das políticas às práticas na formação de professores de línguas estrangeiras. [Dialogues about inclusion: from policiies to practices in foreign language teachers' education]. Campinas: Pontes, p. 63-96.

FULLAN, Michael; HARGREAVES, Andy. 1996. A Escola como Organização Aprendente [What's Worth Fighting in your School]. São Paulo, ARTMED.

GREENWOOK, David; MORTEN, Levin. 2007. Introduction to action research. London: Sage Publication.

HOLZMAN, Lois. 1997. Schools for growth: radical alternatives to current educational models. New Jersey: Lauwrence Brilbaum Associates.

. 2002, Vygotsky's Zone of Proximal Development: The Human Activity Zone. Presentation to the Annual Meeting of the American Psychological Association, Chicago.

JOHN-STEINER, V. 2000. Creative Collaboration. Oxford: Oxford University Press.

KEMMIS, Stephen. 1987. Critical Reflexion. In: WIDEEN, Marvin and ANDREWS, Ian. Staff Development for School Improvement. Philadelphia: The Falmer Press: 73-90.

KINCHELOE, Joe. 1993. A formação do professor como compromisso político: mapeando o Pós-Moderno [Towards a critical politics of teacher thinking: mapping the postmodern]. Porto Alegre: Artmed.

KINCHELOE, Joe; McLAREN, Peter. 2003. Repensando a Teoria Crítica e a Pesquisa Qualitativa. In DENZIN, Norman; LINCOLN, Yvonna e Colaboradores. O Planejamento da Pesquisa Qualitativa: teorias e 
abordagens [The Landscape of Qualitative Research: Theories and Issues]. São Paulo, Artmed, p. 281-313.

LIBERALI, Fernanda Liberali. Building Agency with mobility through perezhivanie (in print).

Transforming Urban Education in São Paulo: Insights into a Collaborative School Project. DELTA. 35:3, 2019 (AOP).

MAGALHÃES, Maria Cecília Camargo. 1990. A Study of teacherresearcher collaboration on Chapter One Reading Instruction. Doctorate Dissertation. College of Education, Virginia Polytechnic Institute \& State University.

. 2009. O método para Vygotsky: A zona proximal de desenvolvimento como zona de colaboração e criticidade criativas. [The method for Vygotsky: zpd as a zone of collaboration and creative criticity] In: SCHETTINI, Rosemary Hohenberger; DAMIANOVIC, Maria Cristina; HAWI, Mona Mohamed; SZUNDY, Paula Taianne Carrera (orgs.). Vygotsky: Uma revisita no início do século XXI. [Vygot1 ${ }^{\text {a }}$ ed. São Paulo: Andross, p. 53-78.

. 2011. Pesquisa Crítica de Colaboração: Escolhas Epistemometodológicas na Organização e Condução de Pesquisas de Intervenção em um contexto escolar. In: MAGALHÃES, Maria Cecília Camargo; FIDALGO, Sueli Salles (eds.). Questões de Método e de Linguagem na Formação Docente. Campinas, São Paulo: Mercado de Letras, p. 13-39.

. 2012. Vygotsky e a Pesquisa de Intervenção no contexto escolar: Pesquisa Crítica de Colaboração (PCCol). In: LIBERALI, Fernanda Coelho; MATEUS, Elaine; DAMIANOVIC, Maria Cristina (eds.). A Teoria da Atividade Sócio-Histórico-Cultural: recriando Realidades Sociais. 1a ed. Campinas: Pontes, p. 13-26.

2014. Escolhas teórico-metodológicas em Pesquisas com formação de professores: como relações colaborativo-críticas na constituição de educadores. In: MATEUS, Elaine; OLIVEIRA, Nilceia Bueno de (eds.). Estudos Críticos da Linguagem e Formação de Professores / como de Línguas: contribuições teórico-metodológicas. Campinas, SP: Pontes Editores, p. 17-48.

MAGALHÃES, Maria Cecília Camargo; FIDALGO, Sueli Salles. 2010. Critical Collaborative Research: focus on the meaning of collaboration and on mediational tools. Revista Brasileira de Linguística Aplicada [Brazilian Journal of Applied Linguistics]. V.10. n. 3: 773-797

2007. The role of methodological choices in investigations conducted in school contexts: critical research on collaboration in continuing teacher education. In: ALANEN, Riika; PÖYHÖEN, Sari 
(eds.). Language in action: Vygotsky and Leontievian legacy today. Cambridge: Cambridge Scholars Publishing.

MAGALHÃES, Maria Cecícila Camargo; NININ, Maria Otília Guimarães; LESSA, Angela Cavenaghi. 2014. A Dinâmica discursiva na Formação de Professores: discurso autoritário ou internamente persuasivo? Bakhtiniana, São Paulo, n ${ }^{\circ} 9$ (1): p.129-47, Jan./Jul. 2014. Disponível em: $<$ http://revistas.pucsp.br/index.php/bakhtiniana/ article/view/17329>. Acessed on 12/20/2015.

MAGALHÃES, Maria Cecília Camargo; OLIVEIRA, Wellington. 2016. Argumentação na Construção de Contextos Colaborativos em Pesquisas de Formação de Educadores. In: LIBERALI, Fernanda Coelho; MATEUS, Elaine; DAMIANOVIC, Maria Cristina; NININ, Maria Otília Guimarães (eds.). Argumentação em Contexto Escolar: relatos de pesquisa. Campinas: Pontes, p. 205-235.

NININ, Maria Otília Guimarães. 2011. Pesquisa e Formação na Perspectiva crítico-colaborativa. In: MAGALHÃES, Maria Cecilia; FIDALGO, Sueli Salles (eds.). Questões de Método e de linguagem na Formação docente [Questions of Method and Language in Teacher Education]. Campinas, SP: Mercado das Letras, p. 187-209.

NUNAN, David. 1986. Research methods in language learning. Cambridge: Cambridge University Press.

PÉREZ GOMEZ, Angel. 1997. O pensamento prático do professor A formação do professor como profissional reflexivo [Teacher's practical thought - teacher's education as a reflective practitioner]. In: NÓVOA, António. Os professores e a sua formação [teachers and their education]. Lisboa: Dom Quixote, p. 93-114.

PENNYCOOK, Alastair. 2001. Critical applied linguistics: a critical introduction. New Jersey: Lawrence Erlbaum Associates.

SPINOZA, Baruch. 1675. Ethica Ordine Geometrico Demonstrata. Iniciado em Rijnsburg e finalizado em Haia em 1675. Acessed on 10/27/2018 at http://www.dominiopublico.gov.br/download/texto/ gu000919.pdf

SPINOZA, Baruch. Tratado Teológico-político (Tractatus TheologicoPoliticus), 1670. Accessed on 10/27/2018 at https://www.centrofic. org/tractatus-theologico-politicus-spinoza/.

STETSENKO, Anna. 2017. The transformative mind: Expanding Vygotsky's approach to development and education. Cambridge: Cambridige University Press.

THIOLLENT, Michel. 2004. Metodologia da pesquisa-ação. [Action Research methodology] São Paulo: Cortez.

VÁZQUEZ, Adolfo Sánchez. 1997. Filosofia da práxis. Rio de Janeiro: Paz e Terra. 
VYGOTSKY, Lev. 1924/1982/1996. Os métodos de investigação reflexológicos e psicológicos. Communication delivered at the II National Conference of Psycho-neurology in Leningrad. In Vygotsky, L. Teoria e método em psicologia. [Method and Theory in Psychology] São Paulo: Martins Fontes.

. (1934) Teoria e Método em Psicologia. [Cambridge, Massachusetts: Harvard University Press, 1978.

. (1934): The Essential Vygotsky. The Collected Works of L.S. Vygotsky. In: RIEBER, R. W. and D. K. ROBINSON (ed.). New York: Plenum, 2004.

(1931) O desenvolvimento Psicológico na Infância. São Paulo: Martins Fontes. 1998. Tradução de Cláudia Berliner.

. (1932): Child Psychology. In: RIEBER, R. W. (ed.). The Collected Works of L. S. Vygotsky. Vol. 5. New York: Plenum, 1987.

. (1934). A Construção do Pensamento e da Linguagem. São Paulo:

Martins Fontes. Tradução de Paulo Bezerra, 2001.

. Psicologia Pedagógica. Trad. Paulo Bezerra. São Paulo: Martins Fontes, 2001.

(1921-23). Educational Psychology. In: DAVIDOV, V. V. (ed.).

New York: Taylor \& Francis, 1997.

. (1934). Problems of General Psychology. In: RIEBER, R. W. (ed.). The Collected Works of L. S. Vygotsky. Vol. 1. New York: Plenum, 1987.

(1932): Early childhood. In: RIEBER, R. W. (ed.). The Collected Works of L.S. Vygotsky. Vol. 5. New York: Plenum, 1998b, p. 261281.

. (1932). O desenvolvimento Psicológico na Infância. São Paulo: Martins Fontes. 1998. Tradução de Cláudia Berliner.

Recebido em: 05/10/2018

Aprovado em: 09/11/2018 